\title{
Late results of aortic valve replacement with the Starr-Edwards prosthesis
}

\author{
C. M. Morgans, D. W. Barritt, R. H. Belsey, G. Keen, and R. Wensley \\ From The Cardiac Department, United Bristol Hospitals
}

Details are presented concerning 59 patients who left hospital between fanuary 1964 and fanuary 1969 after aortic valve replacement with the Starr-Edwards prosthesis. Of the 14 late deaths, 7 are known to have been due to causes related to the prosthesis and 4 to other causes. The 45 surviving patients have nearly all shown clinical improvement and only 3 are unable to work as a result of some complication of the operation. Aortic regurgitation and its consequences appear to be the most significant factor leading to symptoms. In II of I6 patients with anaemia there was evidence of intravascular haemolysis. The long-term consequence of this complication is not known.

Calcific or rheumatic aortic valve disease usually causes progressive disability and early death. Replacement of the diseased valve by a prosthesis or a graft is now the treatment of choice. The Starr-Edwards prosthesis has been used exclusively in this series. Until January I968 the prosthesis contained a silicone rubber ball (model I 200), but subsequently the cloth-covered valve containing a hollow ball made of stellite 21 (model 2300) has been used in most cases. Much interest now centres on the performance of the Starr-Edwards valve over long periods and thus on the late complications. We report here a detailed follow-up of patients who left hospital after aortic valve replacement. Patients who had more than one valve replaced are excluded.

\section{Patients and methods}

Between January 1964 and January 1969, 59 patients left hospital after aortic valve replacement. All were fully investigated before operation. Catheter studies showed that all were in left ventricular failure, and when these results were considered together with the clinical and electrocardiographic findings it was estimated that all patients had reached a stage of the disease when their life expectancy was two years or less. Seven patients in fact died while on the three-month waiting list for surgery. Fourteen of the 59 patients died before this survey was begun and they are discussed later. The 45 surviving patients were seen by us between March and May 1969. A detailed history was followed by an examination during which special attention was given to the assessment of the degree of any aortic regurgitation. Early diastolic murmurs were graded I to 4, grade

Received 10 March 1970.
4 being accompanied by a thrill. Investigations included blood count, reticulocyte count, Rickettsia burnetii complement-fixation test (phase 2), electrocardiogram, and penetrated postero-anterior and lateral chest radiographs. The blood film was examined by a haematologist (R.W.) and particular attention was paid to the degree of red cell fragmentation, which was estimated as slight, moderate, or conspicuous.

\section{Results}

Diagnostic details for the 59 patients are given in Table $I$, two-thirds of the patients having dominant aortic stenosis and one-third aortic incompetence. Of the 20 patients with aortic incompetence, 8 had had bacterial endocarditis. The age range is shown in Table 2. For the 45 surviving patients, the length of followup ranged from 4 to 57 months (Table 3 ). The length of history ranged from 2 months to 12 years, but in 35 patients the first symptom appeared less than 5 years before operation. Symptomatic improvement is shown in Tables 4 and 5. Exercise tolerance improved in all but 6 patients. At follow-up, 23 patients did not admit to being breathless and a further I5 noticed breathlessness only on more than normal exertion. Only 7 became breathless on normal exertion. None of the patients has experienced effort syncope since operation, and angina was less severe in the 5 patients who still noticed it.

An analysis of the patients' work record was made. Housework was included in this, patients who were able to do all their housework being included in the 'full-time' category. Of the 45 patients seen at follow-up, 28 were working full-time, and of these 20 had 
TABLE I Diagnoses in 59 patients leaving hospital after aortic valve replacement with Starr-Edwards prostheses

\begin{tabular}{lrr}
\hline Total: & 59 & \\
Male & 46 & \\
Female & 13 & \\
& & \\
Lesion: & & 33 \\
Aortic & & 7 \\
& & 7 \\
Aortic incompetence-rheumatic & -rheumatic & ro \\
& -bact. endocarditis & 8 \\
& -Reiter's syndrome & I \\
\hline
\end{tabular}

TABLE 2 Age range for 59 patients leaving hospital after aortic valve replacement with Starr-Edwards prostheses (late deaths in brackets)

\begin{tabular}{ll}
\hline Age range & No. of patients \\
\hline $20-29$ & 2 \\
$30-39$ & $5(+2)$ \\
$40-49$ & $13(+4)$ \\
$50-59$ & $21(+7)$ \\
$60-69$ & $4(+1)$ \\
\hline
\end{tabular}

TABLE 3 Length of follow-up of long-term survivors

\begin{tabular}{lc}
\hline Years & No. of patients \\
\hline$<\mathrm{I}$ & 8 \\
$\mathrm{I}-2$ & 12 \\
$2-3$ & 9 \\
$3-4$ & 9 \\
$4-5$ & 7 \\
\hline
\end{tabular}

TABLE 4 Effect of aortic valve replacement on exercise tolerance in 45 long-term survivors

\begin{tabular}{llll}
\hline Grade & Effect & \multicolumn{2}{c}{ No. of patients } \\
\cline { 3 - 4 } & Preop. & Postop. \\
\hline 0 & $\begin{array}{l}\text { Not breathless } \\
\text { Breathless on more than } \\
\text { normal exertion } \\
\text { Breathless on normal } \\
\text { exertion }\end{array}$ & 2 & 23 \\
2 & $\begin{array}{l}\text { Breathless on the flat - } \\
\text { unable to climb one } \\
\text { flight of stairs } \\
\text { Breathless at rest }\end{array}$ & 18 & 7 \\
4 & 2 & 0 \\
\hline
\end{tabular}

TABLE 5 Effect of aortic valve replacement on other symptoms in 45 long-term survivors

\begin{tabular}{lll}
\hline Symptoms & Preoperative & Postoperative \\
\hline Effort syncope & 10 & 0 \\
Angina pectoris & 29 & 5 \\
Congestive cardiac & 16 & 2 \\
$\quad$ failure & & \\
\hline
\end{tabular}

been working until their admission for operation. Ten patients were working parttime and all had been off work for several months before operation. Seven were off work and 2 of these had had their operations relatively recently and were expected to return to work soon. Of the remaining 5 patients, I returned to work as a security officer but subsequently obtained a disability pension because of angina and for other reasons unconnected with his cardiac status. One was incapacitated after a cerebral embolus and 2 had aortic regurgitation with haemolytic anaemia. One of these 2 patients was also in congestive cardiac failure. The fifth patient, a scrap dealer, found it more profitable to remain off work.

\section{Complications}

The late complications are listed in Table 6.

TABLE 6 Complications in 45 long-term survivors

\begin{tabular}{ll}
\hline Complications & No. of patients \\
\hline Aortic regurgitation & 20 \\
Anaemia & 16 \\
Cerebral embolism & 12 \\
Bleeding episodes & 8 \\
Myocardial infarction & I \\
Pulmonary embolism & I \\
\hline
\end{tabular}

Aortic regurgitation An early diastolic murmur was audible in 20 patients $(44 \%)$. In 10 of these there was evidence of haemolytic anaemia and in 2 congestive cardiac failure (Table 7). A further 6 patients required diuretic therapy to keep them free of heart failure. Two of these 20 patients were off work, one having severe haemolytic anaemia and the other moderate haemolytic anaemia and congestive cardiac failure.

Anaemia Sixteen patients had haemoglobin levels below the standards of $13.5 \mathrm{~g} . / 100 \mathrm{ml}$. for men and $11.5 \mathrm{~g} . / 100 \mathrm{ml}$. for women (Sanders, 1965). The degree of anaemia is shown in Table 8. Eleven had fragmentation of red cells, which was accepted as evidence of

TABLE 7 Aortic regurgitation in 45 long-term survivors

\begin{tabular}{lllll}
\hline $\begin{array}{l}\text { Grade of } \\
\text { murmur }\end{array}$ & $\begin{array}{l}\text { No. of } \\
\text { patients }\end{array}$ & $\begin{array}{l}\text { Congestive cardiac } \\
\text { failure (on diuretics) }\end{array}$ & $\begin{array}{l}\text { Not in congestive } \\
\text { cardiac failure but } \\
\text { on diuretics }\end{array}$ & $\begin{array}{l}\text { Haemolytic } \\
\text { anaemia }\end{array}$ \\
\hline I & 6 & 3 & $\begin{array}{l}3 \text { mild } \\
\text { I severe } \\
3 \text { mild } \\
\text { I moderate } \\
\text { I severe }\end{array}$ \\
\hline
\end{tabular}


TABLE 8 Haemoglobin levels in 16 long-term survivors with anaemia

\begin{tabular}{lll}
\hline & Haemolytic & Other \\
\hline Mild (Hb > I I g./100 ml.) & 6 & 5 \\
Moderate (Hb 9-II g./100 ml.) & 2 & 0 \\
Severe (Hb < 9 g./100 ml.) & 3 & $\circ$ \\
\hline
\end{tabular}

haemolysis due to the presence of the prosthesis. Nine of the I I had aortic regurgitation, and 5 had the earlier type of valve and 6 the cloth-covered type. Other causes of fragmentation of red cells such as carcinomatosis and malignant hypertension were excluded on clinical examination. Of the II patients with evidence of haemolysis, 6 had a mild anaemia, the fragmentation of red cells being mild in some and moderate in others, and 5 had moderate or severe anaemia, the fragmentation of red cells being moderate in all cases. Details of these 5 patients are given in Table 9. Two of the 5 had normal reticulocyte counts (less than $2 \%$ ), and in 3 the total serum bilirubin was below $1 \cdot 2 \mathrm{mg}$./100 $\mathrm{ml}$. Case 3 has been persistently jaundiced, and though he was at work when seen in March 1969 he subsequently developed a more profound haemolytic anaemia necessitating a further thorocotomy at which the valve was resutured to the valve ring. Case 2 has had a very severe haemolytic anaemia. He has been studied in Plymouth by Dr. G. R. Steed as well as by us, and the presence of intravascular haemolysis has been repeatedly confirmed. The reticulocyte count has been as high as 40 per cent. Fragmentation of red cells was mild but no other cause for haemolysis has been found. The anaemia responded to bed-rest and there was no evidence of occult or overt gastrointestinal bleeding.

The remaining 5 patients with no evidence of haemolysis were all anticoagulated. Occult blood loss may have contributed to the mild anaemia. One man aged $2 \mathrm{I}$ was investigated in more detail because he had been taking phenobarbitone and phenytoin regularly for idiopathic epilepsy. He was also taking warfarin. As the serum folate was normal and there was no macrocytosis, the anticonvulsant drugs were not implicated. As the serum iron was low, the anaemia may have been due to occult blood loss.

Cerebral embolism Since September 1966, when a patient died after a cerebral embolus, all patients have been anticoagulated from the early postoperative period. Of the Is patients who had their operations before September I966 and were thus not anticoagulated from the early postoperative period, Io have subsequently had episodes attributed to cerebral emboli. In 6 the history was typical and in 4 it was suggestive. All recovered with anticoagulant therapy, though one woman later had a second cerebral embolus while effectively anticoagulated. She remains confused and dysarthric. In addition, I patient had a myocardial infarction in 1967 which may have been due to a coronary embolus or to coronary atherosclerosis. He was started on anticoagulants, made a complete recovery, and has since remained on warfarin. The 4 remaining patients in this group who have not been anticoagulated had their operations $37,49,53$, and 56 months ago, respectively. Of the 30 patients who have been anticoagulated from the early postoperative period, I has had a cerebral embolus and she made a complete recovery.

Bleeding episodes Of $4 \mathrm{I}$ patients on longterm anticoagulants, 8 had bleeding episodes and in 3 the bleeding was from two sites (Table 10). Overt gastrointestinal bleeding occurred in 3 patients. In $I$ it was recurrent and several transfusions were necessary. No local lesion could be shown and the prothrom-

TABLE IO Complications of anticoagulation

\begin{tabular}{ll}
\hline Complications & No. of patients \\
\hline Gastrointestinal bleeding (overt) & 3 \\
Haemoptysis & 2 \\
Haematuria & 2 \\
Epistaxis & 3 \\
Haemarthrosis & I \\
\hline
\end{tabular}

TABLE 9 Details of five patients with haemoglobin levels below II $\mathrm{g} . / 100 \mathrm{ml}$.

\begin{tabular}{|c|c|c|c|c|c|c|c|}
\hline $\begin{array}{l}\text { Case } \\
\text { No. }\end{array}$ & $\begin{array}{l}\mathrm{Hb} \\
\text { level }\end{array}$ & $\begin{array}{l}\text { Fragmentation } \\
\text { of red cells }\end{array}$ & $\begin{array}{l}\text { Reticulocyte } \\
\text { count }(\%)\end{array}$ & $\begin{array}{l}\text { Total } \\
\text { bilirubin }\end{array}$ & $\begin{array}{l}\text { Aortic } \\
\text { regurgitation }\end{array}$ & $\begin{array}{l}\text { Congestive } \\
\text { cardiac failure }\end{array}$ & Work status \\
\hline I & $8 \cdot 6$ & ++ & $1 \cdot 0$ & $\mathbf{I} \cdot \mathbf{I}$ & 0 & - & Full time \\
\hline 2 & $8 \cdot 3$ & ++ & $30 \cdot 0$ & 0.8 & I & - & Off work \\
\hline 3 & $8 \cdot 6$ & ++ & $5 \cdot 0$ & $6 \cdot 6$ & 3 & - & $\begin{array}{l}\text { Full time; subsequently } \\
\text { had further operation }\end{array}$ \\
\hline 4 & $10 \cdot 6$ & ++ & $7 \cdot 5$ & $1 \cdot 5$ & $\circ$ & - & $\begin{array}{l}\text { Off work; recent } \\
\text { operation }\end{array}$ \\
\hline 5 & $9 \cdot 0$ & ++ & $I \cdot O$ & 0.2 & 3 & + & Off work \\
\hline
\end{tabular}


bin time had not been below 40 per cent. Haemoptysis occurred in 2 patients during attacks of acute bronchitis. Two patients noted haematuria and 3 epistaxis. One man developed a haemarthrosis after mild trauma. Despite these complications, withdrawal of anticoagulants was only necessary in the patient with recurrent gastrointestinal bleeding.

Pulmonary embolism One man, aged 54, was admitted four months after operation with calf tenderness, pleural pain and breathlessness of sudden onset, and pyrexia. A diagnosis of pulmonary embolism was made despite his being on anticoagulant therapy. Investigations did not contribute any further evidence and he made a complete recovery.

\section{Investigations}

Chest radiographs Preoperative radiographs were obtained in 44 of the 45 patients and were compared to those taken at followup. Twenty-six of the preoperative radiographs showed cardiac enlargement (cardiothoracic ratio greater than $50 \%$ ). At follow-up, 16 of these had a reduction in cardiothoracic ratio which was greater than Io per cent in 8 (Fig. I). Six of these 8 originally had aortic incompetence. In contrast, of the ro patients who had no reduction in cardiothoracic ratio, 7 had had aortic stenosis. The average length of follow-up for the 8 patients with a Io per cent or greater reduction in cardiothoracic ratio was 36 months, whereas it was only 18 in those with no significant change in heart size.
Possible factors which may be contributing to the persisting cardiomegaly in Io cases include the persistence of aortic regurgitation in 7,5 of whom are also anaemic. There is no obvious cause in the other 3 patients who are all well and at work.

Eighteen of the preoperative radiographs showed normal-sized hearts and 17 of these were from patients who had had aortic stenosis. One was from a man aged 29 who developed severe aortic incompetence after bacterial endocarditis.

In two patients the heart had become larger since operation (Fig. 2). One may well have sustained a myocardial infarction when he developed ventricular fibrillation during cardiac catheterization before operation. The other had aortic incompetence and moderate haemolytic anaemia.

Electrocardiograms Preoperative electrocardiograms were compared with those taken at follow-up (Table I I). Left ventricular hypertrophy was present in 34 of the 45 preoperative tracings (Sokolow and Lyon, 1949). In 31 of these, ST segment depression and T wave inversion were also present, but in 3 there were voltage criteria of left ventricular hypertrophy only. Ten of the remaining II tracings were abnormal, 7 showing ST segment and $T$ wave abnormalities only, $\mathrm{I}$ left bundle-branch block and first degree heart block, I left axis deviation only, and I a high posterior myocardial infarction. Of the 7 electrocardiograms showing ST segment and $T$ wave abnormalities only, 6 were from

FIG. I Decrease in heart size after aortic valve replacement: $(A)$ before operation;

(B) two-and-a-half years after operation.

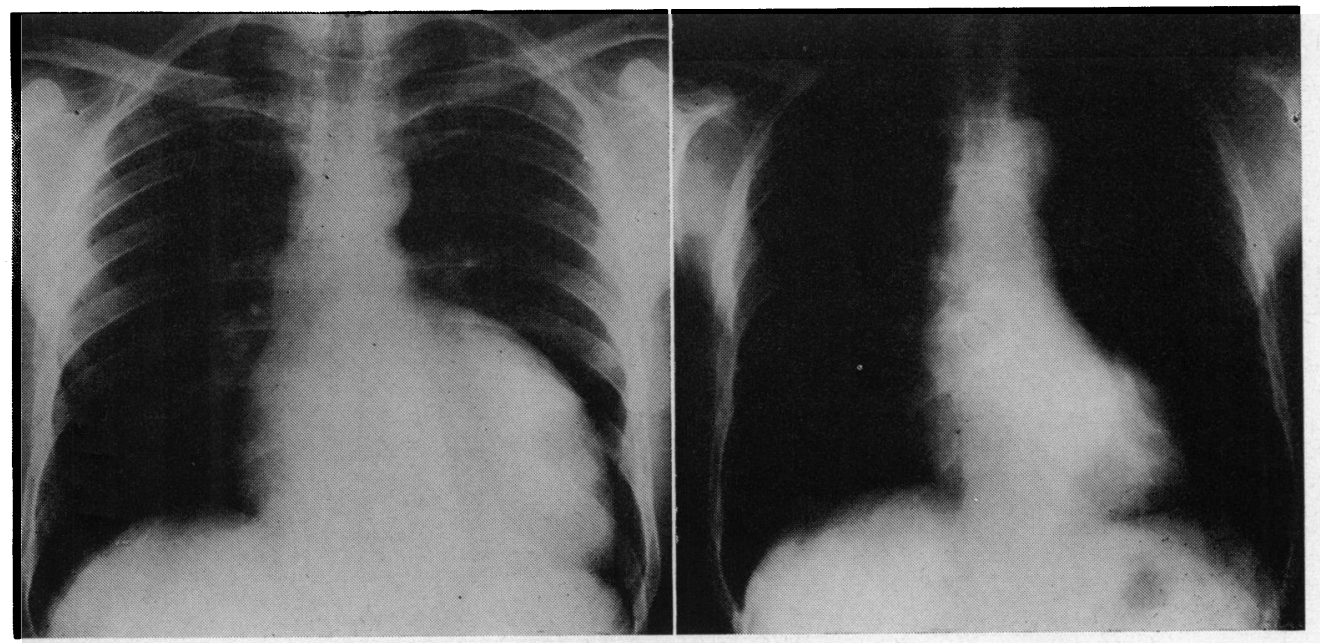




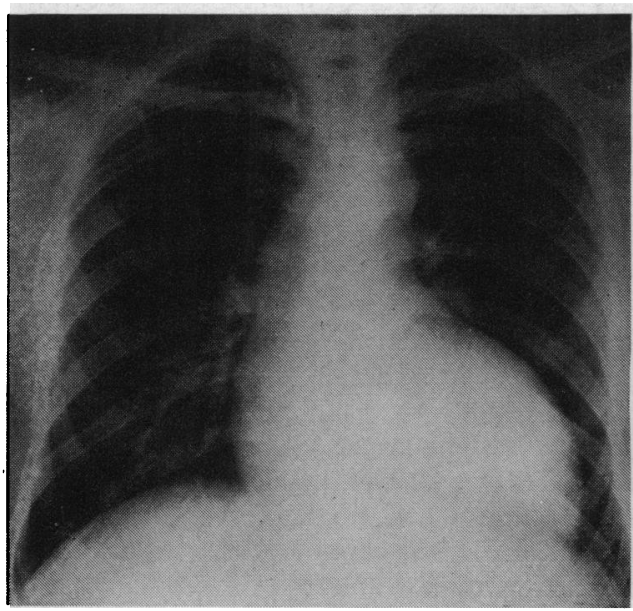

A

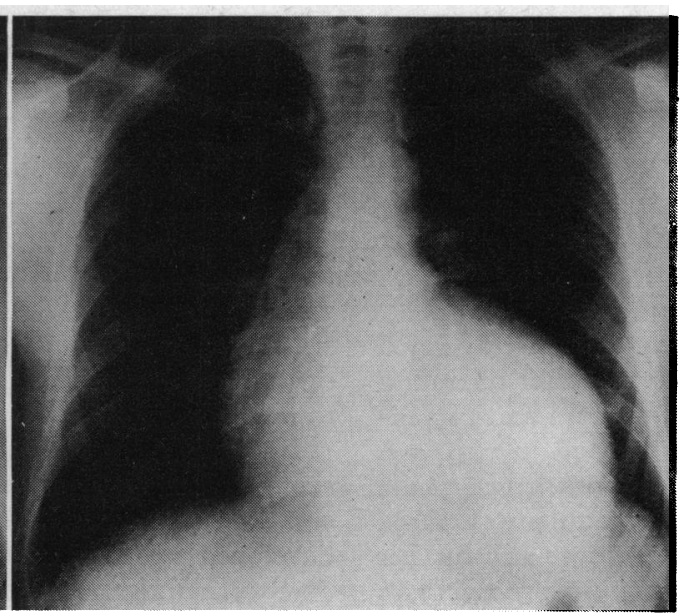

B

FIG. 2 Heart increasing in size despite valve replacement in a patient who may have sustained a myocardial infarction before operation: $(A)$ before operation; $(B)$ two years after operation (aortic reflux absent).

patients with calcific aortic stenosis. In 4 of these 6 , the gradients across the aortic valve had been measured and were 65,80 , roo, and $128 \mathrm{~mm}$. $\mathrm{Hg}$, respectively.

At follow-up, the evidence for left ventricular hypertrophy had either disappeared or was much less conspicuous in 23 tracings (Fig. 3). Six of the Io patients with electrocardiograms showing persisting evidence of left ventricular hypertrophy had originally had aortic incompetence. At follow-up, 5 of them had aortic incompetence. Left bundlebranch block was present in the tracings from
5 patients before operation and all had calcific aortic stenosis. At follow-up this had persisted in 3, disappeared in I (Fig. 4), and in another complete heart block had supervened. The preoperative tracing from I patient showed right bundle-branch block in addition to left ventricular hypertrophy, and at follow-up the right bundle-branch block and the evidence for left ventricular hypertrophy had disappeared, and changes very suggestive of anterior myocardial infarction were seen.

The patient with a normal electrocardiogram before and after operation had calcific

TABLE I I Comparison between pre-operative electrocardiograms and those recorded at follow-up

\begin{tabular}{|c|c|c|c|c|}
\hline \multirow[t]{2}{*}{ Preoperative } & \multirow[t]{2}{*}{ No. } & \multirow[t]{2}{*}{ Follow-up } & \multicolumn{2}{|c|}{ Preoperative diagnosis } \\
\hline & & & $\begin{array}{l}\text { Calcific aortic } \\
\text { stenosis }\end{array}$ & $\begin{array}{l}\text { Aortic } \\
\text { incompetence }\end{array}$ \\
\hline $\begin{array}{l}\text { Left ventricular } \\
\text { hypertrophy }\end{array}$ & 29 & $\left\{\begin{array}{l}\text { ST-T wave changes only } \mathrm{I}_{3} \\
\text { Criteria less marked } 9 \\
\text { No change } 7\end{array}\right.$ & $\begin{array}{r}10 \\
6 \\
2\end{array}$ & $\begin{array}{l}3 \\
3 \\
5\end{array}$ \\
\hline $\begin{array}{l}\text { Left ventricular } \\
\text { hypertrophy and left } \\
\text { bundle-branch block }\end{array}$ & 4 & $\left\{\begin{array}{l}\text { Left bundle-branch block only I } \\
\text { Left ventricular hypertrophy only I } \\
\text { No change } 2\end{array}\right.$ & $\begin{array}{l}\mathbf{I} \\
\mathbf{I} \\
\mathbf{I}\end{array}$ & I \\
\hline $\begin{array}{l}\text { Left ventricular } \\
\text { hypertrophy and right } \\
\text { bundle-branch block }\end{array}$ & $\mathbf{I}$ & Anterior myocardial infarction $\mathbf{r}$ & I & I \\
\hline $\begin{array}{l}\text { ST-T wave abnormalities } \\
\text { only }\end{array}$ & 7 & $\begin{array}{l}\text { No change } 5 \\
\text { Subendocardial anterior myocardial } \\
\text { infarction I }\end{array}$ & 4 & $\mathbf{I}$ \\
\hline $\begin{array}{l}\text { Left bundle-branch block } \\
\text { and first degree heart } \\
\text { block }\end{array}$ & $\mathbf{I}$ & Complete heart block I & $\mathbf{I}$ & \\
\hline Left axis deviation only & $\mathbf{I}$ & No change I & & I \\
\hline $\begin{array}{l}\text { High posterior myocardial } \\
\text { infarction }\end{array}$ & I & No change I & I & \\
\hline Normal & $\mathbf{I}$ & Normal I & I & \\
\hline
\end{tabular}


aortic stenosis with a gradient of $100 \mathrm{~mm} . \mathrm{Hg}$ across the valve.

Eight patients had persisting atrial fibrillation after operation. Four were reverted to sinus rhythm with DC shock and have remained in sinus rhythm. One had complete heart block as well as atrial fibrillation and 3 were digitalized.

Complement-fixation tests Complementfixation tests against Rickettsia burnetii (phase 2) were performed in all patients because of the possibility of this being a subclinical infection and because of the increasing frequency with which cases of $Q$ fever endocarditis involving the aortic valve are being recognized. In every case the titre was less than $\mathrm{I}: 8$.

\section{Late deaths}

Of the 14 late deaths, 7 were due to causes related to the prosthesis, 4 to causes unrelated to the prosthesis, and in 3 cases the patient died suddenly at home and the cause of death was not determined (Table 12).

TABLE 12 Causes of late deaths after aortic valve replacement

\begin{tabular}{|c|c|c|c|}
\hline \multicolumn{2}{|c|}{ Cause of death } & \multirow{2}{*}{$\begin{array}{l}\text { No. of } \\
\text { patients }\end{array}$} & \multirow{2}{*}{$\begin{array}{l}\text { Survival } \\
\text { (mth.) }\end{array}$} \\
\hline \multirow[t]{7}{*}{ I } & Related to prosthesis & & \\
\hline & Valve detachment & 3 & $7,7,26$ \\
\hline & Bacterial endocarditis & I & 4 \\
\hline & $Q$ fever endocarditis & $\mathbf{I}$ & 16 \\
\hline & $\begin{array}{l}\text { Thrombus on prosthesis } \\
\text { occluding coronary }\end{array}$ & & \\
\hline & ostium & $\mathbf{I}$ & 24 \\
\hline & Cerebral embolism & I & 3 \\
\hline \multirow[t]{5}{*}{2} & Unrelated to prosthesis & & \\
\hline & Unrelieved left ventricular & & \\
\hline & $\begin{array}{l}\text { failure } \\
\text { Coronary atheroma with }\end{array}$ & I & 3 \\
\hline & $\begin{array}{l}\text { Coronary atheroma with } \\
\text { thrombosis }\end{array}$ & 2 & 22,38 \\
\hline & Bronchopneumonia & I & 23 \\
\hline 3 & $\begin{array}{l}\text { Sudden death } \\
\quad \text { (no necropsy) }\end{array}$ & 3 & $2,15,22$ \\
\hline
\end{tabular}

Three patients developed aortic incompetence and died in congestive cardiac failure. At necropsy they were shown to have detachment of the prosthesis.

One man developed endocarditis due to Staphylococcus albus. There was little response to treatment and he developed a hemiplegia and died in congestive cardiac failure. At necropsy vegetations were found on the prosthesis which was partially detached. There was also evidence of multiple systemic emboli.

$Q$ fever endocarditis was confirmed by histological and serological methods in one

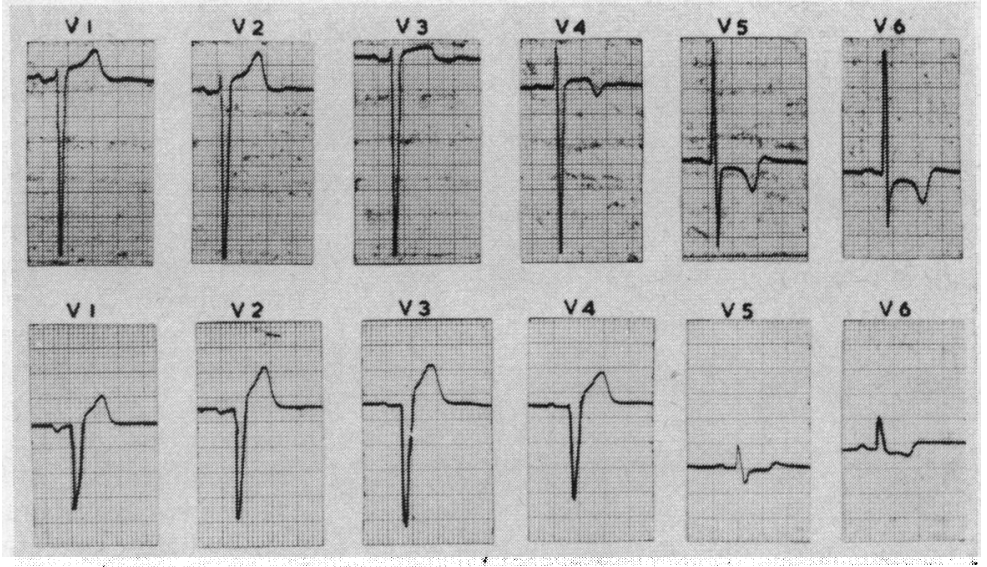

FIG. 3 Chest leads showing left ventricular hypertrophy before valve replacement (upper row) and resolution of changes two-and-a-half years after operation (lower row).

case fully reported elsewhere (Morgans and Cartwright, 1969).

One man presented clinically with myocardial infarction, but was shown at necropsy to have massive thrombus formation around the prosthesis which occluded the left coronary ostium (Fig. 5). He had not been on anticoagulants.

A woman of 47 died after a cerebral embolus, and this led to the introduction of routine anticoagulation as described. At necropsy a rim of material composed of fibrin

FIG. 4 Chest leads showing left bundlebranch block before valve replacement (upper row), with resolution of changes one year after operation (lower row).

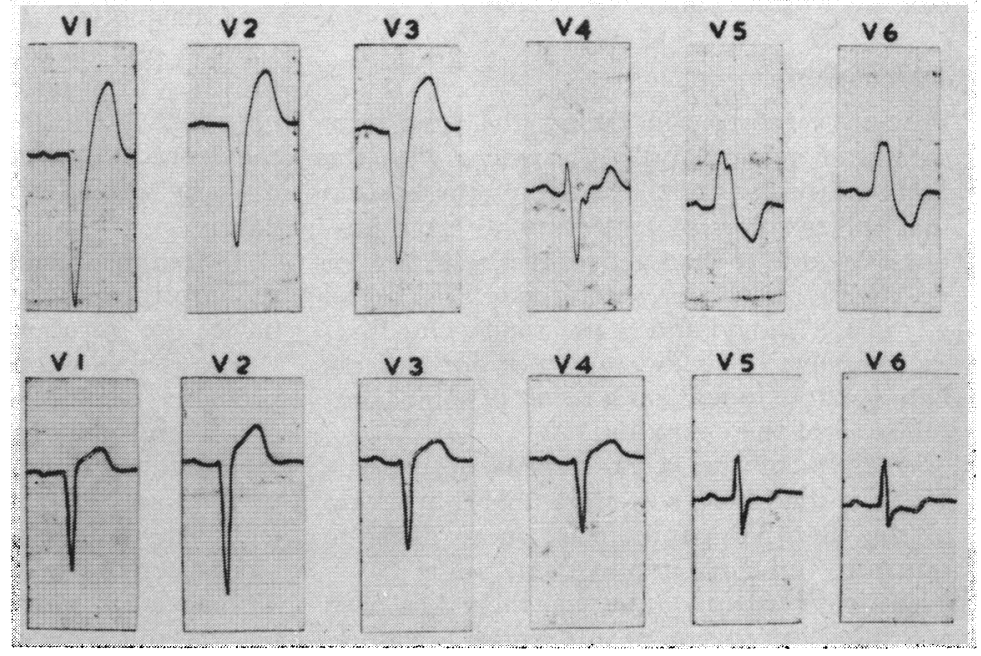




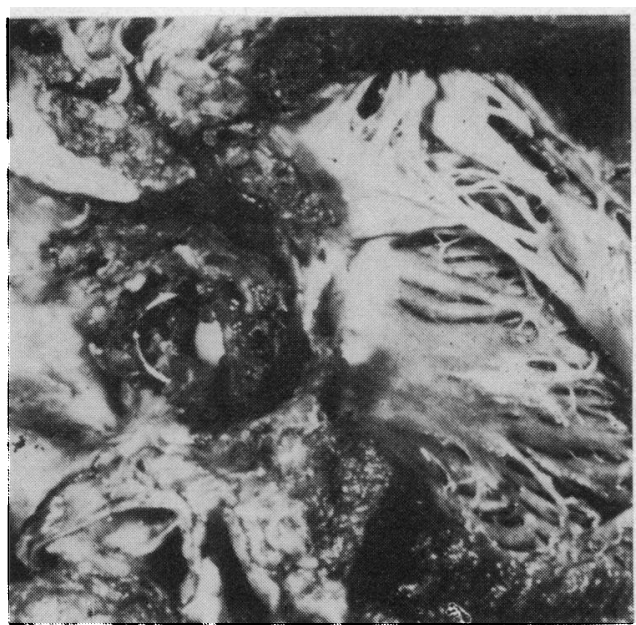

FIG. 5 Massive thrombus around the prosthesis which occluded the left coronary artery.

and platelets surrounded the base of the prosthesis and the same material was shown to be occluding the middle cerebral artery.

A man of 43 who had severe aortic regurgitation before operation died three months later from unrelieved left ventricular failure. At necropsy the left ventricle was massively dilated. No other cause of death was found and it was assumed that the failing myocardium had reached the stage at which recovery was impossible even by correcting the underlying valvular defect.

Two men aged 55 and 58 died after myocardial infarctions. In both cases, thrombus was found at the site of atheromatous occlusion of a coronary artery. In I there was thrombus on the prosthesis but this was laminated, unlike that found in the coronary artery. Coronary embolism was therefore considered most unlikely.

\section{Discussion}

Previous reports concerning the long-term results of aortic valve replacement with the Starr-Edwards prosthesis have emphasized that the majority of patients who leave hospital are able to lead active lives with few or no symptoms (Herr et al., 1968; Fleming et al., 1969; Ahmad and Starr, 1969). Our findings support this view, only 3 of our patients being unable to work as a result of some complication of the operation.

Analysis of the work records of patients suggests that those who were able to work up to the time of operation are more likely to return to full-time employment.

With regard to symptoms, there has been a striking improvement in exercise tolerance, though 7 patients are still breathless on normal exertion. Five patients, all over 45 years old, still experience angina pectoris. In 4 of them the valve appears to be functioning well though in the fifth there is some aortic regurgitation. Thus, coronary artery disease may be responsible and it is notable that coronary atheroma with thrombosis was shown at necropsy in 2 of 3 patients who died of myocardial infarction. Furthermore, one of the surviving patients sustained a myocardial infarction a year after operation, and a further patient developed electrocardiographic changes compatible with myocardial infarction. Coronary arteriography was not done routinely before operation in this series, for in all cases there was evidence that the aortic valve disease was severe and it therefore called for surgical correction.

Aortic regurgitation is a well-recognized complication of this operation. Three of the patients in this series died after valve detachment and a further 20 have early diastolic murmurs. The leak is only associated with an important degree of haemolysis in 3 patients, one of whom also has congestive cardiac failure. One other patient with a grade 2 early diastolic murmur has congestive cardiac failure as well. Though persisting aortic regurgitation is often due to a leak between the base of the prosthesis and the valvular bed it may also be due to ball variance or thrombus forming at the base of the prosthesis usually adjacent to one of the struts. It has not been related in this series to preoperative valvular calcification or to calcification extending into the surrounding tissues.

Of I I patients with haemolytic anaemia, 9 have aortic incompetence. The other 2 may be examples of ball variance presenting with haemolytic anaemia (Miller et al., 1969). However, haemolysis is known to occur in aortic stenosis and in patients with Starr-Edwards prostheses but no regurgitant jet (Brodeur et al., 1965). We have found no relation between the degree of haemolysis and either the grade of early diastolic murmur or the type of valve.

Thrombus formation in association with the prosthesis was a common complication before the introduction of routine anticoagulation. It accounted for 2 late deaths and was probably responsible for at least 6 episodes of cerebral embolism. Since starting routine anticoagulation in the early post-operative period, only I patient has had a cerebral embolus, though I other patient has had a second cerebral embolus while anticoagulated. The need for anticoagulants is one disadvantage of this type of valve replacement, and 
anticoagulation is potentially hazardous. None of our patients with the cloth-covered valve has had an embolus, and the results of Herr et al. suggest that this type of valve becomes endothelialized and that the incidence of thrombus formation is much reduced. Whether patients with cloth-covered valves will be able to discontinue anticoagulants remains undecided.

The 59 patients in this series all had left ventricular hypertrophy at operation, and yet in 22 per cent of the 45 preoperative electrocardiograms studied there were no voltage criteria of left ventricular hypertrophy. Persisting left ventricular hypertrophy after operation appears to be more likely in patients operated on for aortic incompetence. Hypertrophy in aortic incompetence is secondary to ventricular dilatation, whereas in aortic stenosis hypertrophy is the primary response and when the heart increases in size the left ventricle is probably failing. Only I patient in this series has complete heart block.

The practice of performing complementfixation tests against Rickettsia burnetti antigens in patients with aortic valve disease and suspected endocarditis who have negative blood cultures is leading to the diagnosis of an increasing number of cases of $Q$ fever endocarditis. This infection has been recorded in a patient with an aortic valve prosthesis, and it may be seen more often in the future as the number of patients with aortic valve prostheses increases.

There were 8 patients in this series who had developed left ventricular failure in a short time as a result of bacterial endocarditis. Apart from I who died suddenly at home, they are all now symptom free and form a group with a particularly favourable prognosis.

We wish to thank Dr. Susan Clarke of the Public Health Laboratory Service for carrying out the complement-fixation tests.

\section{References}

Ahmad, A., and Starr, A. (1969). Valve replacement in geriatric patients. British Heart fournal, 31, 322.

Brodeur, M. T. H., Sutherland, D. W., Koler, R. D. Starr, A., Kimsey, J. A., and Grisweld, H. E. (1965). Red blood cell survival in patients with aortic valvular disease and ball-valve prostheses. Circulation, 32, 570.

Fleming, J., Hamer, J., Hayward, G., Tubbs, O. S., and Hill, I. (1969). Long-term results of aortic valve replacement with the Starr-Edwards valve. British Medical fournal, 1, 139.

Herr, R. H., Starr, A., Pierie, W. R., Wood, J. A., and Bigelow, J. C. (1968). Aortic valve replacement: A review of six years' experience with the ball-valve prosthesis. Annals of Thoracic Surgery, 6, 199.

Miller, L. B., Pearson, H. A., Wheat, M. W., Jr., White, A. W., Jr., and Schiebler, G. L. (1969). Delayed onset of haemolytic anaemia in a child: an indicator of ball variance in aortic valve prosthesis. Circulation, 40, 55.

Morgans, C. M., and Cartwright, R. Y. (1969). Case of $Q$ fever endocarditis at site of aortic valve prosthesis. British Heart fournal, 31, 520.

Sanders, C. (1965). Some erythrocyte parameters on a cross section of U.K.A.E.A. employees. Laboratory Practice, 14, 1390.

Sokolow, M., and Lyon, T. P. (1949). The ventricular complex in left ventricular hypertrophy as obtained by unipolar praecordial and limb leads. American Heart fournal, 37, 16r. 